\title{
O SILÊNCIO COMO POSSIBILIDADE DE ENCONTRO COM DEUS
}

\section{Uma proposta a partir da teologia de Bruno Forte e do Papa Bento XVI SILENCE AS A POSSIBILITY OF MEETING WITH GOD A proposal from the theology of Bruno Forte and Pope Benedict XVI}

\author{
Geraldo Luiz Borges Hackmann ${ }^{1}$ \\ Ludinei Marcos Vian²
}

\begin{abstract}
RESUMO
O objetivo desse artigo é apresentar o silêncio como possibilidade de encontro com Deus, a partir de pesquisa bibliográfica da teologia de Bruno Forte e de alguns textos do Papa Bento XVI sobre o silêncio e o encontro com Deus. Inicia-se apresentando a importância do encontro para que exista comunicação entre Deus e o ser humano, pois, segundo Bruno Forte, Deus é encontro. Após, a palavra é o meio pela qual Deus, que é a palavra, se comunica com o ser humano no silêncio. Por fim, o lugar privilegiado para o encontro com Deus é o silêncio. Deus, que também é silêncio, está presente no silenciar humano. Nesse encontro, o silêncio de Deus vai ao encontro do silêncio do ser humano e se torna presença a partir da palavra de seu Filho, Jesus Cristo. Assim, conclui-se que há íntima ligação entre encontro, silêncio e palavra, pois o silêncio é o ambiente de encontro com Deus e a sua Palavra, que, desse modo, dialoga com o ser humano, que, por sua vez, responde à Palavra de Deus ouvindo, testemunhando e anunciando a Palavra de Deus.
\end{abstract}

Palavras-chave: Encontro. Silêncio. Palavra. Bruno Forte. Papa Bento XVI.

\begin{abstract}
The objective of this article is to present silence as a possibility of an encounter with God, based on a bibliographical research of Bruno Forte's theology studies and a few texts written by Pope Bento XVI about silence and the encounter with God. Firstly, it will be presented the importance of the encounter for the communication between God and the human being to exist, because, according to Bruno Forte, God is an encounter. Secondly, the word is a mean by which God, Who is word, communicates with the human being in silence. Finally, the privileged place for an encounter with God is silence. God, Whom is also silence, is present in human's silence. On this encounter, God's silence meets the human being's silence and becomes a presence departing from his son's words, Jesus Christ. Thus, it is possible to conclude that there is an intimate connection between encounter, silence, and word, because silence is the place of an encounter with God and His Word, which thus dialogues with the human being, who, in turn, answers to God's Word by listening, witnessing, and proclaiming God's Word.
\end{abstract}

Keywords: Encounter. Silence. Word. Bruno Forte. Pope Bento XVI.

Pontifícia Universidade Católica do Rio Grande do Sul (PUCRS), Programa de Pós-Graduação em Teologia, Porto Alegre, RS, Brasil. E-mail: gborgesh@pucrs.br - ORCID iD: https://orcid.org/0000-0002-6109-9986

Pontifícia Universidade Católica do Rio Grande do Sul (PUCRS), Doutorando no Programa de Pós-Graduação em Teologia, Bolsista da Capes, Porto Alegre, RS, Brasil. E-mail: 1mvian@hotmail.com - ORCID iD: https://orcid.org/0000-0003-1442-2995 


\section{INTRODUÇÃO}

Como o mundo atual está, inevitavelmente, marcado pela comunicação por causa das redes sociais, apesar da fragilidade das mesmas, a presença virtual está tomando, paulatinamente, o lugar da presença física e do encontro interpessoal vis-à-vis, e traz, para muitos internautas, a sensação de tempo preenchido e a ansiedade pela conexão permanente. Diante disto, cabe a pergunta por outro tipo de comunicação: aquela caracterizada pelo silêncio e outra marcada pelo estar diante do outro com atitude de abertura, simplicidade e presença, em busca de diálogo.

O silêncio, apesar do rumor próprio dos aglomerados urbanos, é também uma forma de comunicação, pois possibilita dar a gestos e sentimentos uma nova configuração e abre a perspectiva para nova compreensão do outro e da realidade circundante. Assim, existe uma comunicação não verbal, típica, por exemplo, dos poetas, dos enamorados, dos místicos, que é expressão de sensibilidade, simplicidade, humildade e, também, de uma profunda atitude de fé, enquanto aponta para Deus.

O presente texto visa apresentar o silêncio como uma possibilidade de encontro com Deus, fruto de pesquisa bibliográfica na área da antropologia teológica. O ponto de partida é a busca de analisar e compreender a teologia de Bruno Forte, onde se encontra a afirmação da necessidade do silêncio para perceber a presença de Deus, pois ele também se comunica por meio do silêncio, além de alguns textos do Papa Bento XVI, onde se encontram afirmações análogas. O texto está dividido em três pontos. O primeiro aborda a necessidade e a importância do encontro; o segundo aborda o silêncio como meio da comunicação de Deus para o ser humano através da palavra, que é seu próprio filho Jesus Cristo; e o terceiro ponto estuda o silêncio como lugar do encontro com Deus. Essa comunicação no silêncio impulsiona a pessoa para estar com Deus, com ele interagir, e perceber o convite para anunciar e testemunhar a maravilha do encontro com Deus, a fim de que outras pessoas possam fazer essa mesma experiência.

\section{O MISTÉRIO DO ENCONTRO INTERPESSOAL}

Toda comunicação requer um encontro. Se não houver o encontro, não existe comunicação. E esta comunicação interpessoal se estende ao ato pessoal da fé, que, por isso mesmo, não se distancia da necessidade de comunicação entre os seres humanos. A fé, por ser um ato tipicamente humano, também se situa no nível pessoal. A história da salvação demonstra a permanente comunicação de Deus com a humanidade, por isso, essa comunicação só é possível no encontro da pessoa humana com Deus, no qual o divino e o humano abrem seu mistério um para com o outro, resultando em um verdadeiro momento de encontro interpessoal.

Por vezes é utilizado o argumento da distinção entre o divino e o humano, pois, Deus como Ser supremo, tornar-se-ia distante do ser humano e, por isso, impossível o estabelecimento de encontro e presença, afirmando uma sociedade distante de Deus ${ }^{3}$. O erro desse argumento, segundo Joseph Ratzinger, é o enquadramento de Deus em uma imagem meramente humana, ou seja, imaginando-o a maneira humana ${ }^{4}$. Diante disso, Bruno Forte afirma que Deus, em sua essência, é encontro 5 . Por ele ser encontro, não se afasta da obra criada, mas, ao contrário, está presente em todos os momentos de sua 
história. E a sua presença mais significativa pode ser descrita a partir de suas próprias palavras: "Se me amais, observais meus mandamentos, e rogarei ao Pai e ele vos dará outro Paráclito, para que convosco permaneça para sempre, o Espírito da Verdade" ( $J o$ 14,15-17). Quer dizer, que através do Espírito Santo acontece a sua presença no amor. O Espírito Santo, dom do amor do Pai por meio de Jesus Cristo, torna possível e real o encontro entre Deus e a humanidade. Além de oportunizar esse encontro entre Deus e o ser humano, o Espírito Santo também o possibilita entre as pessoas da Santíssima Trindade, que tem no encontro a sua essência.

Bruno Forte explica como o Espírito Santo exerce a função de unir as pessoas da Santíssima Trindade através do encontro:

Vinculum caritatis aeternae, laço do eterno amor, o Espírito é, portanto, ao mesmo tempo, aquele que une o Amante e o Amado e aquele que, em relação a ambos, se distingue por ser Pessoa específica (...) É sob esta luz que surge a ideia de que o Espírito procede do Pai e do Filho (Filioque), ou seja, do diálogo eterno do amor de ambos, do face a face de ambos, que é reciprocidade no dom, gratuidade e gratidão, expansividade e acolhimento recíprocos ${ }^{6}$.

E esse vínculo trinitário, que se dá através do amor, segundo Bruno Forte, continua agindo ao realizar o encontro com a humanidade. Assim, já a criação é obra do transbordamento do amor de Deus (CEC 295-300), e que, como sua fonte infindável, mantém a obra criada pelo amor da origem, o primeiro amor, que tudo criou sem ser criado e criou pelo simples fato de amar ${ }^{7}$.

No amor, Deus transmite o seu amor por meio do encontro no Espírito. O amor é como o ar, que está presente em todo lugar e dá a vida ao ser humano. Assim é o amor de Deus. Todavia, surge a questão da liberdade humana, que pode refutar o amor e se negar a comparecer ao encontro, tornando-o impossível e irrealizável. E é o que acontece muitas vezes na sociedade atual: com o intuito de respeitar a vivência da fé das pessoas, independentemente de sua configuração, setores da sociedade se abstêm da fé, ou seja, livremente negam a possibilidade do encontro com Deus no amor. E o ser humano, que vive nessa sociedade, se vê diante da possibilidade de agir da mesma forma: respeita quem crê, mas rejeita a possibilidade pessoal do ato de fé, assumindo uma existência sem fé e distanciada de Deus. Essa constatação revela que o crer só é possível a partir do encontro com Deus, que apela para uma possível resposta livre e responsável na fé por parte do ser humano ${ }^{8}$.

O Papa Bento XVI aprofunda esta reflexão sobre a possibilidade da resposta humana dada pela fé à iniciativa divina impelida pelo amor. Na introdução da Carta Encíclica Deus caritas est, o Papa Bento XVI afirma que "no início do ser cristão, não há uma decisão ética ou uma grande ideia, mas o encontro com uma Pessoa que dá à vida um novo horizonte e, dessa forma, o rumo decisivo" (Deus caritas est, n. 1). Esta pessoa é Jesus Cristo. A Carta Encíclica Lumen Fidei, publicada pelo Papa Francisco, ressalta a fé como dom de Deus e como aceitação humana, que provoca o ir do ser humano ao encontro do mistério divino. Assim, a fé se dá no encontro: "A fé nasce do encontro com Deus vivo, que nos chama e revela o seu amor: um amor que nos precede e sobre o qual podemos apoiar-nos para construir solidamente a vida" (Lumen Fidei, n. 4).

FORTE, B. Teologia da História, p. 160.

Cf. FORTE, B. Teologia da História, p. 251.

Papa Bento XVI alerta, através de uma alegoria, sobre o risco da sociedade ignorar o trabalho da teologia. A teologia que tem o trabalho de anunciar e fundamentar a fé. Cf.: BENTO XVI. Introdução ao Cristianismo, p. 31-33. 
Na mesma Carta Encíclica, o Papa Francisco cita alguns exemplos dessa dinâmica. Deus vai ao encontro do ser humano através do amor, e a fé se dá pelo encontro. Mas como Deus não pode obrigar o ser humano a comparecer ao encontro, o ser humano estará presente nele através do crer ou não crer, ou seja, se aceitar essa dinâmica acontecerá através da fé (Cf. Lumen Fidei, n. 8-22).

A história de Abraão, o do pai na fé, demonstra que Deus vai a seu encontro e promete uma descendência numerosa, apesar de ele não compreender de que maneira isso se acontecerá. Abraão já é idoso e sua esposa Sara ainda não tem filhos. Mas, mesmo na incerteza e diante da iniciativa divina, Abraão mantem-se fiel a Deus, guiado exclusivamente pela fé, que o faz confiar na promessa divina. E quando Deus cumpre a promessa ao lhe dar o filho, Abraão está diante de um novo desafio: Deus pede que seu filho seja oferecido em sacrifício. Mesmo diante de prova tão dura, Abraão mantém a sua fé em Deus: Deus providenciará, responde ele ao filho $(G n 22,8)$. Ele confia na providência de Deus. E aqui está presente novamente a mesma dinâmica da iniciativa divina e da reposta humana pela fé.

Ao longo da história de Israel, vemos inúmeros exemplos semelhantes. A missão de Moisés inicia no encontro da sarça ardente e Moisés torna-se o intermediário entre Deus e o povo de Israel. (Lumen Fidei, n. 13-14) A fé despertada por Deus torna possível não só o encontro com de Moisés com Ele, mas mantém vivifica a fé da comunidade. Além de Moisés a encíclica traz como exemplo Abraão, o pai na fé (Lumen Fidei, n. 8-11), chegando em Jesus que "é a manifestação plena da fiabilidade de Deus" (Lumen Fidei, n. 15). Ainda apresenta Paulo que se abriu a graça da fé e tornou-se testemunho de Cristo (Lumen Fidei, n. 19-22).

Por fim, o encontro com Deus proporciona um encontro com o outro de forma diferenciada. Como a reflexão anterior aponta para a categoria de encontro presente na essência de Deus, esse mesmo Deus é desejoso de encontrar-se com o ser humano, proporcionando, por sua vez, o encontro com outro ser humano. Esse encontro com o outro ganha qualidade na medida em que foi precedido por um encontro com o Transcendente, pois torna possível esse encontro com o outro tornar-se um esvaziamento de si para preencher-se do outro, assumindo, desse modo, uma responsabilidade em relação ao outro.

Graças à responsabilidade pelo outro que o sujeito sai realmente do encarceramento de si, rompe a totalidade ilusória de seu mundo e aceita tornar-se refém do outro. Só então, na inquietude para com o outro levada até a substituição, o eu atinge realmente a si mesmo, livre dos grilhões do próprio mundo absoluto, para reencontrar-se no ter-se perdido por causa e em favor do outro?.

A partir desta reflexão sobre o encontro, parte-se, daqui em diante, para a exposição da palavra como possibilidade de encontro com Deus. E este encontro por meio da palavra apela para o silêncio, que abre o caminho para a pessoa humana se colocar em sintonia com Deus e escutá-lo. O diálogo comporta em falar e escutar.

\section{A PALAVRA COMO MEIO DE ENCONTRO COM DEUS}

Como o intuito do artigo é apresentar o silêncio como local do encontro com Deus, parece contraditório afirmar que no silêncio exista diálogo. O Papa Bento XVI, na audiência geral do dia 7 de março de 2012, fala da oração de Cristo como exemplo da dinâmica da palavra e do silêncio. Cristo muitas vezes se retira para rezar, e, na oração, ele se coloca diante do Pai. Esta atitude de Jesus de se colocar diante do Pai em oração pessoal e silenciosa não significa que ela seja muda e que não estabeleça um diálogo.

FORTE, B. À escuta do Outro, p. 114. 
O Papa Bento XVI vê na dinâmica entre a palavra e o silêncio a possibilidade de amadurecer a relação com Deus, pois, ao silenciar diante de Deus, o ser humano é capaz de entrar em contato com o divino, porquanto o silêncio favorece o escutar e o conhecer melhor a si mesmo, provocando o nascimento e o aprofundamento do pensamento, a compreender com maior clareza ${ }^{10} \mathrm{e}$, desse modo, dá início ao movimento de abertura ao outro e ao divino e possibilita o acolhimento da Palavra de Deus, que exige "o silêncio interior e exterior, para que tal palavra possa ser ouvida"11.

O grande desafio, prossegue o Papa Bento XVI, é o de conseguir silenciar em meio ao barulho da sociedade atual, porque o silêncio pode trazer o medo da pessoa humana se separar do mar de palavras e imagens que a circundam. Diante desse desafio, ele orienta para que a pessoa faça um esforço de educar-se para o silêncio. E ele aponta que o principal benefício é o da abertura ao mistério e à reflexão sobre si mesmo. Quando existe o silêncio, a comunicação de Deus se dá por diversos meios, mas principalmente pela sua palavra expressa na Sagrada Escritura. Escutar a Deus através da Sagrada Escritura, oportunizada pelo silêncio, abre espaço para a reflexão da Palavra de Deus e aplica-la na vida de cada pessoa.

Bruno Forte afirma que a Palavra é o Filho (cf. Jo 1,14) e o Pai é o silêncio. Todavia, o Pai sai do Silêncio ao se manifestar na Palavra, que é o seu Filho, Jesus Cristo ${ }^{12}$. O Papa Bento XVI também faz menção do silencio como um espaço privilegiado do encontro com Deus afirmando que: "a solidão e o silêncio constituem espaços privilegiados para ajudar as pessoas a encontrar-se a si mesmas e àquela Verdade que dá sentido a todas as coisas"13.

Diante da realidade do permanente barulho e da dificuldade de perceber Deus que se comunica com o ser humano, Bruno Forte se refere a Deus que se comunica ao ser humano através da Palavra. Apesar de parecer contraditório, para Bruno Forte, silêncio e palavra estão intimamente ligados. Por isso, não é equivoco afirmar que no silêncio existe uma comunicação de Deus, e essa comunicação se dá por meio de sua Palavra ${ }^{14}$.

Na dinâmica do silêncio e da palavra, muitos se questionam sobre os momentos em que não sentem ressoar a voz de Deus em suas vidas. Essa sensação faz parte da chamada noite escura, desertos de secura na fé, conforme relatam muitos místicos e santos. Todavia, esse silêncio não significa ausência. Segundo o Papa Bento XVI, o aparente silêncio de Deus deve ser vivido como uma oportunidade para enraizar e aprofundar a fé, "quanto mais abertos permanecemos ao seu e ao nosso silêncio, tanto mais começamos a conhecê-lo realmente. Esta confiança extrema que se abre ao encontro profundo com Deus amadurece no silêncio" 15 .

Para Bruno Forte, "o silêncio é o seio fecundo do advento, o cenário em que ressoa a Palavra, o espaço do último dia. O silêncio, porém, é assim porque é eco de outro silêncio, aquele em que o mistério ficou envolto por séculos, aquele de onde a Palavra procede" Para Bruno Forte, o silêncio, que é seio fecundo, é o humano. Ele se torna assim a partir do encontro com o outro silêncio, que provém de Deus, e de onde a Palavra procede. A comunicação existe porque antes existiu o encontro no silêncio; mas a Palavra está no Silêncio e dele procede.

BENTO XVI. Silêncio e Palavra: Caminho de Evangelização, p. 5.

BENTO XVI. Audiência Geral - Praça São Pedro em 07/03/2012.

Bruno Forte desenvolve sua teologia sobre o Pai como Silêncio, o Filho como Palavra e o Espírito Santo como Encontro principalmente no livro: FORTE, B. Teologia da História, p. 63-201.

3 BENTO XVI. Silêncio e Palavra: Caminho de Evangelização, p. 8.

14 Para Bruno Forte "a Palavra que se torna presente na história está com Deus desde toda a eternidade. O Verbo encarnado é aquele que eternamente procede do eterno Silêncio e, ao mesmo tempo, é aquele que, pela sua natureza humana, pertence a este mundo: a Palavra feita carne é revelação e presença do Eterno na precisão e unicidade de evento deste mundo". FORTE, B. Teologia da História, p. 120. BENTO XVI. Audiência Geral - Praça São Pedro em 07/03/2012.

FORTE, B. Teologia da História, p. 95. 
Desta forma, ao Silêncio divino corresponde um silêncio humano: enquanto, porém, o primeiro é a casta Fonte do Verbo, a Origem sem origem e o Princípio sem princípio de toda a divindade, início silencioso de tudo o que existe por pura gratuidade do ato criador, o silêncio terreno é apenas preparação, destinatário, acolhimento, espaço aberto para o surpreendente novo início, escuta à espera de ser fecundado pela Palavra ${ }^{17}$.

A Palavra, que é comunicada no silêncio, é o Filho. O prólogo do evangelho de João é um dos argumentos apresentados por Bruno Forte para justificar a afirmação de que o Filho é a Palavra que sai do silêncio, que é o Pai: "No Princípio era o Verbo e o Verbo estava com Deus e o Verbo era Deus. No princípio, ele estava com Deus. Tudo foi feito por meio dele e sem ele nada foi feito. E o Verbo se fez carne, e habitou entre nós" ( $J o$ 1,1-3;14). Para Bruno Forte, a dupla especificação, Verbo e carne, onde o primeiro é a Palavra, "nos indica por um lado, a distinção eterna entre o Verbo e esse Deus com o qual ele estava; por outro lado, a total igualdade no plano do ser divino entre aquele que era Deus com quem ele estava" ${ }^{18}$. Portanto, se Deus está no encontro, por consequência ele também está na Palavra e no silêncio. A iniciativa é sempre divina, e ao ser humano cabe estar disposto a acolher esse advir de Deus.

Através da Palavra, que é o Cristo, Deus se revela e, por isso, torna a Palavra o meio eficaz da presença de Deus na história da humanidade. "A Palavra de revelação requer ser transcendida, não no sentido de que se possa ser eliminada ou posta indiferentemente entre parênteses, (...) mas no sentido de que é verdade e vida precisamente enquanto é caminho" 19 . O ser humano, ao se colocar diante de Deus no encontro, necessariamente terá a Palavra por companhia, porque através dela Deus se revela. Assim, a Palavra de Deus, ouvida no silêncio, se torna o caminho seguro e verdadeiro pelo qual o ser humano deve seguir para alcançar a vida plena.

Se a Palavra é uma indicação de caminho verdadeiro, também o é o do sentido. Isso quer dizer que o ser humano encontra sentido para sua vida através da Palavra. Essa afirmação abre um novo caminho para aquelas pessoas que têm dificuldade de encontrar um rumo para sua vida, não do ponto de vista profissional, mas para sua existência enquanto ser humano. Esse contexto instiga Bruno Forte a perceber a possibilidade de a teologia tornar-se facilitadora do encontro entre Deus e o ser humano. De um lado está o ser humano que busca algo, um sentido para a sua vida pessoal; do outro lado, está Deus, que deseja ir ao encontro do ser humano. Bruno Forte se utiliza de duas categorias para explicar esse movimento: o êxodo humano e o advento divino. Êxodo corresponde ao sair de uma situação de escravidão para a libertação. Da mesma forma como o povo de Israel, como narra o Antigo Testamento, foi liberto por Deus da escravidão do Egito, hoje o ser humano necessita ser liberto da escravidão da falta de sentido e do pecado. Deus continua a ouvir o clamor de seu povo, a exemplo do Antigo Testamento, e advém ao encontro do ser humano. Desse modo, para Bruno Forte, a teologia cristã tem a "tarefa de levar à palavra a esperança, suscitar e plasmar a inteligência do seu próprio êxodo e do êxodo da Igreja e do mundo em vista de um futuro prometido do Reino, para ter um conhecimento a exercer uma reflexão sobre a realidade a partir do fim" 20 .

Se existe um ser humano que está em um movimento de saída e um Deus que realiza o movimento de ir ao encontro do ser humano, a Palavra é a forma de comunicação entre o êxodo humano e o advento divino. E a Palavra parte do silêncio. A iniciativa é divina, porque a reponsabilidade pela libertação também é divina. Da mesma forma que Deus

FORTE, B. Teologia da História, p. 95.

FORTE, B. Teologia da História, p. 105.

FORTE, B. A escuta do Outro, p. 51.

FORTE, B. A teologia como companhia, memória e profecia, p. 46. 
libertou o povo da escravidão do Egito, ele hoje sai de seu Silêncio e vem ao encontro do ser humano. E isso se dá através de sua Palavra, capaz de libertar o ser humano da escravidão do pecado.

A Palavra, que é Jesus Cristo, veio ao mundo para trazer a salvação. O mundo que estava na escravidão do pecado e da morte encontra em Jesus Cristo sentido para vida. Caminho seguro e verdadeiro para a salvação. Para compreender a maravilha do mistério da revelação torna-se necessário realizar o encontro que se dá no silêncio, no qual Deus se revela a partir da palavra. E, assim, o silêncio se converte em ambiente para um encontro real com Deus, como a seguir será explicitado.

\section{O SILÊNCIO COMO MEIO DE ENCONTRO COM DEUS}

Até aqui se foi exposto duas categorias, o encontro e a palavra, e se abriu o caminho para entender que a encontro com a Palavra se dá por meio do silêncio. Mas é preciso aprofundar. Será mesmo que é através do silêncio, muitas vezes difícil nos dias de hoje, que a pessoa humana consegue encontrar a Deus? A quinta Conferência Geral do Episcopado Latino-Americano e do Caribe, em Aparecida, em 2007, cita diversos ambientes onde é possível acontecer um encontro com Deus que ser revela em Jesus Cristo. O texto conclusivo dessa Conferência do CELAM, ao convidar o fiel para estar com o Mestre, a escutá-lo, estar próximo e encontrar-se com ele, descreve alguns lugares nos quais é possível haver encontro com Jesus Cristo:

O encontro com Cristo, graças à ação invisível do Espírito Santo, realiza-se na fé recebida e vivida na Igreja. (...) encontramos Jesus na Sagrada Escritura, lida na Igreja. A Sagrada Escritura (...) é, com a tradição, fonte de vida para a Igreja e alma de sua ação evangelizadora. (...) Encontramos Jesus Cristo, de modo admirável, na Sagrada Liturgia. (...) A Eucaristia é o lugar privilegiado do encontro do discípulo com Jesus Cristo. (...) O sacramento da reconciliação é o lugar onde o pecador experimenta de maneira singular o encontro com Jesus Cristo, que se compadece de nós e nos dá o dom de seu perdão misericordioso ${ }^{21}$.

Além desses lugares acima citados, as conclusões de Aparecida citam outros, como: a oração pessoal e comunitária, a comunidade viva de fé, nos pobres, aflitos e enfermos. Por fim dedica um ponto específico onde destaca a piedade popular como lugar para o encontro com Jesus ${ }^{22}$.

Todavia, o documento de Aparecida não apresenta o silêncio como um lugar da presença de Deus e, portanto, de encontro com Deus. O silêncio, por ser importante na vida das pessoas e da sociedade, merece destaque, pois revela a presença de Deus também nos momentos de dor e de sofrimento. Para Bruno Forte, o silêncio humano se faz principalmente na dor e na oração. Na dor, muitas vezes, um grito de angústia irrompe o silêncio. Como Jesus Cristo na cruz: "Por que me abandonastes?" (Mc 15,34). Mas, diante do inaudito, o silêncio é a principal palavra. Nesse silêncio encontra-se Deus, nele Deus está presente e encontra o ser humano. Logo, o silêncio é também o lugar do encontro com Deus. Para Bruno Forte, o silêncio é Deus ${ }^{23}$.

CELAM. Documento de Aparecida, n. 246-254.

Cf. CELAM. Documento de Aparecida, n. 255-265.

Sobre as palavras de Bruno Forte da presença de Deus na dor de Cristo e da humanidade cf.: FORTE, B. Jesus de Nazaré, história de Deus, Deus da história. p. 282-296. 
O Papa Bento XVI, na mensagem para o dia mundial das comunicações de 2012, escreve que o caminho de evangelização se dá pelo silêncio e pela palavra. Ele afirma que o silêncio faz parte da comunicação:

O silêncio é parte integrante da comunicação e, sem ele, não há palavras densas de conteúdo. No silêncio, escutamo-nos e conhecemo-nos melhor a nós mesmos, nasce e aprofunda-se o pensamento, compreendemos com maior clareza o que queremos dizer ou aquilo que ouvimos do outro, discernimos como exprimir-nos ${ }^{24}$.

Portanto, para o Papa Bento XVI, o silêncio, parte integrante da comunicação, é capaz de comunicar quando há escuta, construindo, assim, uma relação plena. E esse silêncio torna-se lugar do encontro com Deus, pois o silêncio faz aflorar a sensibilidade humana, condição para perceber o que há de mais íntimo no próprio eu humano. Desse modo, quando o silêncio se torna o espaço de encontro com Deus, o que está no âmago do ser humano, o eu, se encontra com Deus ${ }^{25}$.

Mas, para isso, é preciso compreender a presença de Deus no silêncio. Segundo Bruno Forte, Deus é silêncio e nele se manifesta a sua presença. Para tal, é necessário remeter-se ao mistério da revelação. Mas a revelação de Deus não pode ser compreendida somente como o que se mostra ou o que é trazido à tona. Para bem compreendê-la, Bruno Forte se utiliza de um termo alemão: Offenbarung ${ }^{26}$. Este termo amplia a compreensão de revelação, pois além de indicar o que é mostrado, revelado, ao mesmo tempo indica o ato de velar, esconder. Afirmar que Deus que se revela além de implicar na compreensão de um Deus que se dá a conhecer, ao mesmo leva a entender que ele permanece velado, pois ele é mais do que se afirma ${ }^{27}$. Assim, Deus permanece no silêncio. E se ele permanece no silêncio, significa que ele é silêncio. Logo, Deus está presente no silêncio e o silêncio se torna um lugar de encontro com Deus.

De acordo com o Papa Bento XVI, no momento de silêncio o ser humano entra em diálogo com o seu mais íntimo, com a possibilidade de aflorar sua sensibilidade. E seguindo Bruno Forte, esse silêncio é Deus, e, por consequência, se tem a possibilidade do encontro com Deus no silêncio. Diante disto, conclui-se, também, que o silêncio não é o espaço da ausência de Deus, mas sim de sua presença. Ou seja, mesmo nos momentos de silêncio humano, provocados pela dor, pelo sofrimento, pelo sentimento de ausência de Deus, ele está presente, porque ele é silêncio.

Se Deus não fosse silêncio, ele seria incomunicável. Bruno Forte alerta para isso ao refletir sobre o termo alemão Offenbarung:

A consequência que deriva de tudo isso para a compreensão do ato hermenêutico é que o ato cognoscitivo, o realizar-se da interpretação, é um ato total, sem sobras. Como no momento em que o eu conhece o Deus que se revela, conhece inseparavelmente também a lei eterna e necessária do que ele mesmo é e do que são o mundo e a vida, porque no Deus que se revela está o Todo (...) que se revela; assim o ato hermenêutico, todo ato de conhecimento do outro, será uma exposição daquilo que já existe eternamente, uma repetição da identidade! ${ }^{28}$

24 BENTO XVI. Silêncio e Palavra: Caminho de Evangelização, p. 5.

25 Cf.: BENTO XVI. Silêncio e Palavra: Caminho de Evangelização, p. 5-9.

26 Bruno Forte entende a palavra Offenbarung da seguinte forma: A religião cristã é a religião da "offenbarung", porque nela nos é dito totalmente o que Deus é. Não há resíduos, restos, resistências. O cristianismo é a manifestação do Outro, o puro desvelar-se dele. A revelatio resolve-se totalmente na offenbarung: removido o véu, o que estava atrás dele exibe-se em sua pureza, oferece-se à apreensão. A ideia abraça o divino, o conhecimento abre-se acolhedor à plena manifestação de Deus. (Cf. FORTE, B. A escuta do outro, p. 15).

27 Cf. VIAN, L. M. O silêncio de Deus diante do sofrimento humano na teologia de Bruno Forte, p. 32.

28 FORTE, B. À escuta do outro, p. 22. 
Logo, se Deus não for silêncio, presente também em seu ato de velamento, não haverá a surpresa e a novidade e será sempre a repetição do mesmo, uma simples repetição do que já foi trazido à tona, ou seja, não haverá comunicação. Assim, só é possível o encontro surpreendente com Deus se houver o silêncio. E o silêncio deixa de ser um mero ambiente do encontro com Deus para se tornar o espaço essencial do encontro com Deus. Sem o silêncio, entendido como velar-se, os demais lugares de encontros acima elencados não trariam a novidade do divino, pois sem o silêncio os demais espaços de encontro com Deus não seriam possíveis.

$\mathrm{Na}$ audiência geral do dia sete de março de 2012, o Papa Bento XVI reforça a ideia de que Deus fala por meio do silêncio e toma como ponto de partida a cruz de Cristo ${ }^{29}$. Mesmo na experiência do distanciamento do Onipotente e Pai, Cristo revela sua íntima ligação com o Pai pela fé. O distanciamento não significa abandono, esquecimento, mas é a oportunidade do eu, da manifestação e do respeito à individualidade. O encontro no silêncio apresenta dois interlocutores que se comunicam: Deus, que se compadece da sua obra criada, e o ser humano, que se abre ao mistério divino. Mas, mesmo havendo essa íntima relação, não se anulam as diferenças entre o criador e a criatura, entre o infinito e o finito. Mas a diferença não significa distanciamento, pois a cruz mostra-se como o lugar de maior aproximação de Deus à condição humana. Graças à cruz de Jesus Cristo, houve a plenitude da aproximação do divino com o humano, pois aquele que morreu na cruz era verdadeiramente homem e Deus (Cf. DH 301-302). Deus Pai, que se revela no silêncio, faz o ser humano compreender que o silêncio presente na cruz foi, ao mesmo tempo, distanciamento e aproximação. O encontro com Deus no silêncio é uma rica intimidade, mas também um distanciamento. Um distanciamento que mostra a diferença entre Deus e o ser humano e que se abre para o exercício da liberdade, pois a relação de Deus para o ser humano não é possessiva, mas respeitosa da autonomia de sua criatura. É que o amor liberta e o vínculo entre as partes se realiza no amor.

Ao mesmo tempo em que existe o distanciamento e o respeito da individualidade das pessoas, existe também uma íntima ligação. Seguindo a dinâmica própria do ato de revelar, Deus, quando se autocomunica e se mostra, torna-se Palavra.

O revelar-se de Deus é um ato livre e gratuito de sua autocomunicação, onde é necessário preservar e comunicar. O Pai é identificado com o Silêncio, sua comunicação se dá através do Filho que é Palavra. Essa relação é, ao mesmo tempo, união e distinção. União, porque por meio da Palavra chega-se ao Silêncio. Distinção, porque o Silêncio nem todo é Palavra. Falar da relação entre Palavra e Silêncio é, segundo Forte, afirmar que falar de Cristo é calar e calar sobre Cristo significa falar. Quando a Palavra é Silêncio, ela é adoração do mistério e quando fala. Ela é sempre, ao mesmo tempo, incompleta e revolucionária, inesperada ${ }^{30}$.

Para Bruno Forte, o Espírito Santo é decisivo nesta dinâmica de encontro com Deus no silêncio. O Espírito Santo é descrito como encontro. Da mesma forma que existe uma íntima ligação entre silêncio e palavra, existe também uma íntima ligação entre o Pai e o Filho. Quem possibilita este encontro é o Espírito Santo. E ao realizar o encontro entre o Pai e o Filho, faz acontecer o encontro do ser humano com Deus. No silêncio por meio da Palavra do Pai, que é o Verbo (cf. Jo 1,14). Diante disto, Bruno Forte entende Deus Pai como silêncio, Deus Filho como Palavra e Deus Espírito Santo como Encontro ${ }^{31}$. 


\section{CONCLUSÃO}

Com a facilidade atual para comunicação, surgem dificuldades antes não existentes. Entre elas pode-se elencar a extrema necessidade de estar informado, de se expressar e participar das redes sociais, resultando em uma busca incessante de informações sobre os mais diversos setores e aspectos do mundo e da vida. Cada vez mais essa realidade se faz presente no dia-a-dia das pessoas, influenciando suas vidas e seu modo de agir frente às situações. Diante disso, o silêncio se constitui em verdadeiro e grande desafio, que, mesmo em relação ao barulho característico dos grandes aglomerados urbanos e do estresse daí advindo, é procurado por muitas pessoas, que sentem necessidade de um momento de relaxamento e de encontrar-se consigo mesmas.

Ao longo do texto procurou-se evidenciar a importância do silêncio como ambiente do encontro do Deus. Seguindo a teologia de Bruno Forte, a primeira conclusão é que existe uma íntima ligação entre encontro, silêncio e palavra. Em um segundo momento é importante destacar que o silêncio é um ambiente de encontro com Deus e sua palavra. No silêncio a sensibilidade humana aflora e é ela a comunicar-se com o silêncio, que é Deus. Um terceiro ponto é que esse encontro gera diálogo, onde Deus se comunica através de sua Palavra e o ser humano maravilhado percebe que lhe deve uma resposta, estabelecendo-se, assim, a de comunicação com Deus. Por fim, a comunicação gera três compromissos: o primeiro deles é a consciência da missão de anunciar a palavra de Deus, chamando os irmãos ao diálogo com Deus ${ }^{32}$; o segundo é a necessidade de formação para poder dar uma resposta adequada aos desafios próprios do nosso tempo e, entre eles, está o silêncio. O ser humano que encontra Deus no silêncio se sente enamorado por Ele e quer conhecer sempre mais seus mistérios. O terceiro é o testemunho pessoal, fruto da experiência pessoal de Deus, de alguém que se aproximou dele para conhece-lo e dar uma resposta de amor, e, que daí em diante, se sente motivado e responsabilizado em colocar em prática o que aprendeu.

\section{REFERÊNCIAS}

BÍBLIA. Português. A Bíblia de Jerusalém. Nova edição rev. e ampl. São Paulo: Paulus, 2002.

CATECISMO DA IGREJA CATÓLICA. Petrópolis: Vozes; São Paulo: Loyola, 1993.

CONFERÊNCIA GERAL DO EPISCOPADO LATINO-AMERICANO E DO CARIBE. Documento de Aparecida. Texto conclusivo a V Conferência. São Paulo: Paulinas; São Paulo: Paulus; Brasília: Edições CNBB, 2007. https://doi.org/10.5962/bhl.title.110909

DENZINGER, H.; HÜNERMANN, P. Compêndio dos símbolos, definições e declarações de fé e moral. São Paulo: Paulinas e Loyola, 2007.

FORTE, Bruno. À escuta do Outro. Filosofia e revelação. São Paulo: Paulinas, 2003.

FORTE, Bruno. A guerra e o silêncio de Deus. Comentário teológico na atualidade. São Paulo: Paulinas, 2004.

FORTE, Bruno. A Teologia como Companhia, Memória e Profecia. Introdução ao sentido e ao método da teologia como história. São Paulo: Paulinas, 1991.

32 Na Exortação Apostólica Gaudete et Exsultate o Papa Francisco pede que: "Também tu precisas de conceber a totalidade da tua vida como uma missão. Tenta fazê-lo, escutando a Deus na oração e identificando os sinais que Ele te dá. Pede sempre, ao Espírito Santo, o que espera Jesus de ti em cada momento da tua vida e em cada opção que tenhas de tomar, para discernir o lugar que isso ocupa na tua missão" (Gaudete et Exsultate, n. 23). Esse mesmo apelo a missão já foi manifesto pelo Papa Paulo VI na Exortação Apostólica Evangelii Nuntiandi e pelo próprio Papa Francisco na Exortação Apostólica Evangelii Gaudium. 
FORTE, Bruno. Jesus de Nazaré, história de Deus, Deus da história. Ensaio de uma cristologia como história. 2 ed. São Paulo: Paulinas, 1985. https://doi.org/10.17771/pucrio.acad.15643

FORTE, Bruno. Teologia da História. Ensaio sobre a revelação, o início e a consumação. São Paulo: Paulus, 1995.

FORTE, Bruno. Viver com Amor. Sobre a fé e a experiência de Deus. Aparecida: editora Santuário, 2016.

PAPA BENTO XVI. Audiência Geral. Praça São Pedro, 07 de março de 2012. Disponível em: http://w2.vatican.va/content/benedict-xvi/pt/audiences/2012/documents/hf_ben-xvi_aud_20120307.html. Acesso em: 12 jun. 2018. https://doi.org/10.29386/reb.v67i268.1492

PAPA BENTO XVI. Deus caritas est. São Paulo: Paulinas, 2006.

PAPA BENTO XVI. Discurso do Papa Bento XVI. Sessão inaugural dos trabalhos da V Conferência Geral do Episcopado da América Latina e do Caribe. Aparecida, 2007. Disponível em: http://w2.vatican.va/ content/benedict-xvi/pt/speeches/2007/may/documents/hf_ben-xvi_spe_20070513_conference-aparecida. html. Acesso em: 20 jun. 2018.

PAPA BENTO XVI. Introdução ao Cristianismo. Preleções sobre o Símbolo Apostólico. Com um novo ensaio introdutório. 4 ed. São Paulo: Loyola, 2011.

PAPA BENTO XVI. Silêncio e Palavra: Caminho de evangelização. Dia Mundial das Comunicações Sociais, São Paulo: Paulus, 2012.

PAPA FRANCISCO. Evangelii Gaudium. São Paulo: Paulinas, 2013.

PAPA FRANCISCO. Lumen Fidei. São Paulo: Paulinas, 2013.

PAPA FRANCISCO. Gaudete et Exsultate. São Paulo: Paulinas, 2018.

PAPA PAULO VI. Evangelii Nuntiandi. São Paulo: Paulinas, 1975.

VIAN, Ludinei Marcos. O silêncio de Deus diante do sofrimento humano na teologia de Bruno Forte. 2014. 107 f. Dissertação (Mestrado em Teologia) - Faculdade de Teologia, Pontifícia Universidade Católica do Rio Grande do Sul, Porto Alegre, 2014. https://doi.org/10.24873/j.rpemd.2018.06.219.

Recebido: 03/09/2019

Aceito: 03/10/2019

Publicado: 29/12/2019

Endereço:

Geraldo Luiz Borges Hackmann

Paróquia N. Sra. da Piedade, R. Cabral, 546 - Rio Branco, Porto Alegre - RS, CEP: 90420-121. 